\title{
PEMISAHAN ION LOGAM KROM DARI LIMBAH ELEKTROPLATING MENGGUNAKAN POLIEUGENOL DENGAN TEKNIK MEMBRAN CAIR
}

\author{
Sri Intan Permatasari' ${ }^{1}$, Muhammad Cholid Djunaidi ${ }^{*}$, habibi ${ }^{1}$ \\ ${ }^{1}$ Departemen Kimia FSM Universitas Diponogoro, Semarang Jawa Tengah \\ choliddjunaidi@live.undip.ac.id
}

\begin{tabular}{|l|}
\hline $\begin{array}{l}\text { Artikel Info } \\
\text { Diterima }\end{array}$ \\
tanggal \\
12.12 .2018 \\
Disetujui \\
publikasi \\
tanggal \\
30.04 .2019 \\
Kata kunci : \\
Edible film, \\
ekstrak kunyit, \\
gliserol, pati \\
ganyong, sifat \\
mekanik
\end{tabular}

\begin{abstract}
ABSTRAK
Telah dilakukan penelitian tentang pemisahan ion logam krom dari limbah elektroplating menggunakan polieugenol dengan teknik membran cair. Teknik pemisahan logam berat dengan membran cair merupakan salah satu pengembangan metode ekstraksi pelarut, keberhasilan ekstraksi pelarut dan teknik pemisahan menggunakan membran cair ditentukan oleh kestabilan kompleks antara logam dan senyawa pembawa. Polieugenol dapat dimanfaatkan sebagai senyawa pembawa dalam metode pemisahan logam dengan menggunakan teknik membran cair ruah (BLM, Bulk Liquid Membrane), sedangkan polimerisasi eugenol menjadi polieugenol dilakukan dengan menggunakan katalis $\mathrm{H}_{2} \mathrm{SO}_{4}$ pekat. Hasil senyawa eugenol dan polieugenol di analisis dengan GC, spektra FT-IR, dan spektra ${ }^{1} \mathrm{H}$ NMR. Hasil penelitian menunjukkan bahwa 300 gram minyak cengkeh yang di isolasi menjadi eugenol dan disintesis dengan katalis asam sulfat pekat menghasilkan 3,166 gram polieugenol, polieugenol tersebut mempunyai berat molekul 66836,19 (407 monomer). Limbah krom direduksi dari $\mathrm{Cr}(\mathrm{VI})$ menjadi $\mathrm{Cr}$ (III) yang hasilnya digunakan untuk pemisahan logam berat dengan teknik BLM, yaitu divariasikan $\mathrm{pH}$ fasa umpan $1,3,5$, dan 7 , sedangkan $\mathrm{pH}$ fasa penerima dibuat tetap $(0,523)$. Hasil persen transport dengan polieugenol hasil sintesis dengan katalis $\mathrm{H}_{2} \mathrm{SO}_{4}$ pekat dengan variasi $\mathrm{pH}$ pada fasa umpan adalah $\mathrm{pH} 1$ sebesar 20,88 \%, pH 3 sebesar 40,16 \%, pH 5 sebesar 101,42\%,
\end{abstract} dan $\mathrm{pH} 7$ sebesar $89,52 \%$.

\section{ABSTRACT}

Research on separation of chromium ions of metals from electroplating waste using polieugenol with liquid membrane technique. The mechanical separation of heavy liquid membranes metals is one of the methods of development of the extraction with solvents, success of solvent extraction and liquid membrane separation technique that is used is determined by the stability of complexes between a metal and a carrier compound. Polieugenol can be used as a carrier compound in metal separation method using bulk liquid membrane (BLM), while the polymerization of eugenol into polieugenol performed using concentrated $\mathrm{H}_{2} \mathrm{SO}_{4}$ catalyst. Results compounds eugenol and polieugenol on analysis by GC, FT-IR spectra, and ${ }^{1} \mathrm{H}$ NMR spectra. The results showed that 300 grams of clove oil and eugenol in isolation can be synthesized with concentrated sulfuric acid catalyst produces polieugenol 3.166 grams, polieugenol has a molecular weight 66836,19 (407 monomer). Chromium waste is reduced from $\mathrm{Cr}$ (VI) to $\mathrm{Cr}$ (III) whose results are used for the separation of heavy metals with the BLM technique (Bulk Liquid Membrane), varying the $\mathrm{pH}$ of the feed phase 1,3,5, and 7, while the $\mathrm{pH}$ of receiving phase was made permanent $(0,523)$. Results percent of transport with polieugenol synthesized with the catalyst of concentrated $\mathrm{H}_{2} \mathrm{SO}_{4}$ to $\mathrm{pH}$ variations in the feed phase is $\mathrm{pH} 1$ at $20,88 \%, \mathrm{pH} 3$ at $40,16 \%, \mathrm{pH} 5$ at $101,42 \%$, dan $\mathrm{pH} 7$ at $89,52 \%$.

doi: http://dx.doi.org/10.23960/aec.v4.i2.2019.p14-29

Anal.Environ.Chem.Anal.Environ.Chem. 


\section{PENDAHULUAN}

Metode pemisahan yang paling baik dan populer adalah ekstraksi pelarut, karena dapat dilakukan baik dalam tingkat makro maupun mikro (Khopkar, 1990). Teknik pemisahan dengan membran cair merupakan salah satu pengembangan metode ekstraksi pelarut. Keuntungan metode dengan sistem membran cair adalah mempunyai selektivitas dan efisiensi sistem tinggi, mengurangi penggunaan jumlah pelarut dan pemisahan ion dapat dilakukan secara kontinu dalam satu unit operasi. Sistem transport selektif ion melalui membran cair organik dapat digunakan untuk pemisahan ion logam termasuk pemisahan isotop, pemisahan senyawa organik yang sulit dicapai dengan metode lain, pengayaan, atau pengambilan ulang (Hiratani, 1990).

Keberhasilan ekstraksi pelarut dan teknik pemisahan menggunakan membran cair ditentukan oleh kestabilan kompleks antara logam dan senyawa pembawa. Kestabilan kompleks tersebut ditentukan oleh beberapa faktor, diantaranya jenis atom donor (gugus fungsi aktif) dan senyawa pembawa yang sesuai dengan konfigurasi elektron logam (Peterson, 1996). Keuntungan penggunaan senyawa pembawa dalam membran cair adalah untuk meningkatkan efisiensi dan selektivitas transport dan untuk menggabungkan dua tipe mekanisme transport (Bartsch dan Way, 1996).

Indonesia merupakan salah satu negara yang memiliki kawasan hutan tropis yang luas dan beragam kekayaan alam hayati. Salah satu jenis tanaman yang dapat dimanfaatkan adalah cengkeh (Eugenia caryophyllata). Indonesia belum dapat memprosesnya lebih lanjut hingga menjadi suatu produk yang mempunyai nilai ekonomis lebih tinggi (Sastrohamidjojo, 2004). Menurut FAO, Indonesia menghasilkan hampir 80\% dari output dunia pada tahun 2005 diikuti oleh Madagaskar dan Tanzania (Sudarma,2009). Minyak daun cengkeh mempunyai dua komponen utama, yaitu eugenol (sekitar 80 sampai 85\%) dan kariofilen (sekitar 10 sampai 15\%) (Sastrohamidjojo, 2004). Eugenol dapat digunakan sebagai bahan awal suatu senyawa karena adanya tiga gugus fungsional yang terikat padanya, yaitu gugus alil, hidroksi, dan metoksi. Melalui gugus alil, eugenol mampu dipolimerisasi menjadi polieugenol (Ngadiwiyana, 1996, Ciszewsky, 1999, Handayani, 1999, Rastuti, 1998). Sedangkan dari gugus hidroksil telah dapat disintesa gugus-gugus dengan keaktifan yang lebih besar, seperti karboksilat (Harwati, 2002, Lusiana, 2003,Handayani, 2004). Eugenol yang mengalami polimerisasi menjadi polieugenol, yang relatif baru dilakukan, juga dapat dimanfaatkan dan dikembangkan, salah satunya adalah 
penggunaan polieugenol sebagai carrier (senyawa pembawa) dalam recovery fenol (Kiswandono, 2016) dan logam berat. Recovery logam berat ini perlu dilakukan, salah satunya adalah untuk menangani limbah sebelum dibuang ke lingkungan, karena kandungan logam berat yang terdapat dalam limbah dapat mencemari lingkungan dan membahayakan kehidupan di sekitarnya. Berbagai Industri yang bertanggung jawab atas pelepasan logam berat ke lingkungan melalui perairan limbah mereka, diantaranya pertambangan, hidrometralurgi, pulp dan kertas, petrokimia, kilang, pupuk, elektroplating, dan lain-lain. Menurut kesehatan dunia (WHO) logam yang menjadi perhatian khusus yaitu kromium, tembaga, seng, besi, merkuri, dan timah (Leon, 2007).

Pada penelitian sebelumnya dilakukan pemisahan ion $\mathrm{Cr}^{3+}$ dari larutan limbah simulasi menggunakan teknik membran cair ruah BLM (Bulk Liquid Membrane), sedangkan pada penelitian ini dilakukan pemanfaatan polieugenol untuk pemisahan logam $\mathrm{Cr}^{3+}$ dari limbah elektroplating dengan teknik membran cair.

\section{METODE}

\section{Alat dan Bahan}

Alat-alat yang digunakan adalah Peralatan gelas laboratorium, neraca analisis Mettler200, 1 set distilasi fraksinasi pengurangan tekanan, $\mathrm{pH}$ meter (HACH E C20), spektrofotometer serapan aAtom (perkin Elmer), FT-IR (Nicolete Avatar 360), ${ }^{1} \mathrm{H}$ NMR (JEOL-MY60), 60 hz, GC HP5890, seperangkat alat refluks, seperangkat alat BLM (Bulk Liquid Membrane). Bahanbahan yang digunakan adalah minyak cengkeh, metanol teknis, dietil eter teknis, akuades, $\mathrm{HCl}$ p.a, petroleum eter, $\mathrm{NaOH}$ p.a, limbah cair elektropating, $\mathrm{na}_{2} \mathrm{SO}_{4}$ anhidrat.

\section{Prosedur}

\section{Isolasi Eugenol}

300 gram minyak daun cengkeh diekstraksi dengan $\mathrm{NaOH} 1,61 \mathrm{~mol}(64,39$ gram/450 mL air). Lapisan bawah (lapisan air,B1) mengandung garam eugenolat, sedangkan lapisan atas (A1) adalah lapisan organik. Lapisan A1 diekstraksi dengan larutan $0,1 \mathrm{~mol} \mathrm{NaOH}(4$ gram/400mL air) terbentuk 2 lapisan, diambil lapisan bawah (B2). Lapisan B1 digabung dengan B2 diekstraksi dengan petroleum eter $3 \times 50 \mathrm{~mL}$. Lapisan bawah (lapisan air, B3) mengandung garam eugenolat dan lapisan atas (A3) adalah lapisan organik. Lapisan B3 diasamkan dengan 
$\mathrm{HCl} 25 \%$ hingga $\mathrm{pH}=3$ kemudian diekstraksi dengan petroleum eter. Terbentuk 2 lapisan, lapisan atas (A4) mengandung eugenol, sedangkan lapisan bawah (B4) mengandung $\mathrm{NaCl}$. Lapisan B4 diekstraksi dengan petroleum eter $2 \times 50 \mathrm{~mL}$, diambil lapisan atas (A5), kemudian lapisan A5 digabung dengan lapisan eugenol (A4). Setelah itu dicuci dengan aquades sampai netral kemudian ditambah $\mathrm{Na}_{2} \mathrm{SO}_{4}$ anhidrat.

Disaring selanjutnya dievaporasi untuk menguapkan petroleum eter. Residu ditimbang dan difraksinasi dengan destilasi bertingkat pengurangan tekanan. Fraksi yang diperoleh dari isolasi eugenol dikarakterisasi dengan kromatografi gas dan spektrofotometer inframerah.

\section{Sintesis Polieugenol dengan Katalis $\mathrm{H}_{2} \mathrm{SO}_{4}$}

5 gram eugenol dimasukkan dalam labu leher tiga kemudian ditambahkan $0,25 \mathrm{~mL}$ $\mathrm{H}_{2} \mathrm{SO}_{4}$. Campuran diaduk menggunakan stirer selama 1 jam dan setiap 1 jam sekali dilakukan penambahan $\mathrm{H}_{2} \mathrm{SO}_{4}$ sebanyak $0,25 \mathrm{~mL}$ selama 3 jam. Setelah reaksi tersebut berlangsung selama 4 jam, polimerisasi dihentikan dengan menambahkan $1 \mathrm{~mL}$ metanol. Gel yang terbentuk kemudian dilarutkan dengan dietileter dan dicuci dengan akuades hingga $\mathrm{pH}$ netral. Larutan tersebut kemudian dikeringkan dengan menambahkan $\mathrm{Na}_{2} \mathrm{SO}_{4}$ anhidrat. Setelah benar-benar bebas dari air, larutan diuapkan pada suhu kamar. Endapan yang terbentuk dilarutkan dengan akuades, dikeringkan dan ditimbang (Handayani, 2001).

\section{Pengukuran Berat Molekul Polimer}

Sebanyak 1 gram polieugenol dilarutkan dalam metanol hingga konsentrasi $0,04 \mathrm{~g} / \mathrm{mL}$, dan dibuat variasi konsentrasi larutan melalui pengenceran dengan metanol: 0,02 g/mL; 0,01 $\mathrm{g} / \mathrm{mL}$ dan $0,005 \mathrm{~g} / \mathrm{mL}$. Kemudian dilakukan pengukuran waktu alir pelarut murni $\left(\mathrm{t}_{\mathrm{o}}\right)$, yaitu metanol dan masing-masing konsentrasi larutan polimer menggunakan viskosimeter Ubbelohde, sehingga diperoleh $t_{0}, t_{1}, t_{2}, t_{3}$ dan $t_{4}$. Melalui perhitungan, diperoleh viskositas relatif $\left(\eta_{\text {rel }}\right)$ dan viskositas spesifik $\left(\eta_{\mathrm{sp}}\right)$. Kemudian dibuat kurva viskositas tereduksi $\left(\eta_{\mathrm{sp}} / \mathrm{C}\right)$ lawan konsentrasi (C). Selanjutnya grafik tersebut diektrapolasi ke konsentrasi nol, sehingga akan diperoleh viskositas intrinsik $[\eta]$. Dengan persamaan Mark-Houwink-Sakurada $[\eta]=\mathrm{KM}_{\mathrm{v}}{ }^{\mathrm{a}}$ (Hartomo, 1993), maka dapat dihitung massa molekul relatif polieugenol dengan harga $\mathrm{K}=11 \times 10^{-3}$ dan a = 0,725 (Brandrup dan Immergut, 1975).

doi: http://dx.doi.org/10.23960/aec.v4.i2.2019.p14-29

Anal.Environ.Chem.Anal.Environ.Chem. 


\section{HASIL DAN PEMBAHASAN}

\section{Isolasi Eugenol dari Minyak Cengkeh}

Minyak cengkeh dapat diperoleh dari bunga, batang dan daun cengkeh dengan cara distilasi uap. Komponen utama minyak cengkeh adalah eugenol dan karofilena serta senyawasenyawa lain dalam jumlah yang kecil. Eugenol mempunyai gugus fenol (senyawa fenolat) bersifat asam, sedangkan kariofilen merupakan senyawa hidrokarbon sehingga keduanya dapat dipisahkan yaitu dengan menambahkan larutan $\mathrm{NaOH}$. Eugenol akan menjadi garam eugenolat yang larut dalam air, sedangkan kariofilena sebagai senyawa hidrokarbon yang tidak larut dalam air (Busroni, 2000).

Pada molekul eugenol, atom $\mathrm{H}$ pada atom oksigen diserang oleh basa $\mathrm{NaOH}$ membentuk natrium eugenolat. Karena keduanya mempunyai sifat yang berbeda di dalam air, maka akan berada pada fasa yang berbeda sehingga dapat dipisahkan dengan metode ekstraksi pelarut. Petroleum eter dipakai untuk mengekstrak kariofilena dari larutan garam eugenolat yang sudah terpisahkan. Kemudian garam eugenolat diasamkan dengan $\mathrm{HCl}$ pekat hingga $\mathrm{pH}$ larutan $=3$ untuk membentuk eugenol.

Selanjutnya diekstrak dengan petroleum eter dengan tujuan untuk mendapatkan eugenol, untuk menetralkan eugenol yang diperoleh eugenol dicuci dengan akuades sampai netral agar sisa asam yang ditambahkan larut dalam air. Untuk memurnikan eugenol maka eugenol didistilasi dengan fraksinasi pengurangan tekanan. Distilasi pengurangan tekanan dilakukan untuk menghindari kerusakan senyawa yang didistilasi (eugenol) sebagai akibat pemanasan yang terlalu tinggi. Pada umumnya senyawa yang memiliki titik didih tinggi (di atas $150{ }^{\circ} \mathrm{C}$ ) mudah mengalami peruraian sebagian atau seluruhnya sebelum tercapai titik didih normalnya. Hal ini menyebabkan senyawa tersebut tidak dapat dipisahkan dari campurannya dengan distilasi biasa pada tekanan atmosfer. Distilasi pengurangan tekanan ini akan menyebabkan titik didih senyawa tersebut berkurang sehingga senyawa tersebut akan mendidih pada suhu yang lebih rendah dari titik didih normalnya.

Hasil yang diperoleh dari distilasi eugenol terdiri dari empat fraksi. Masing-masing fraksi memiliki kemurnian yang berbeda-beda yaitu fraksi I, II, III, IV kemurniannya 88,78 \%, 90,54 $\%, 92,12 \%$ dan $97,65 \%$. Eugenol yang paling murni diperoleh pada fraksi yang ke empat yaitu pada suhu $160{ }^{\circ} \mathrm{C}$. Eugenol yang diperoleh sebanyak 38,4 ml berupa cairan jernih kekuningan. 
Kemudian keempat fraksi tersebut dianalisis dengan kromatografi gas untuk menguji kemurniannya. Pada kromatogram fraksi IV muncul puncak dengan TR 5,862 menit dengan kemurnian eugenol sebesar 97,65\%.

Eugenol yang mendekati murni tersebut dianalisis menggunakan FTIR. Analisis senyawa hasil spektrofotometer IR memberikan spektrum pada Gambar 2 dan Tabel 1.

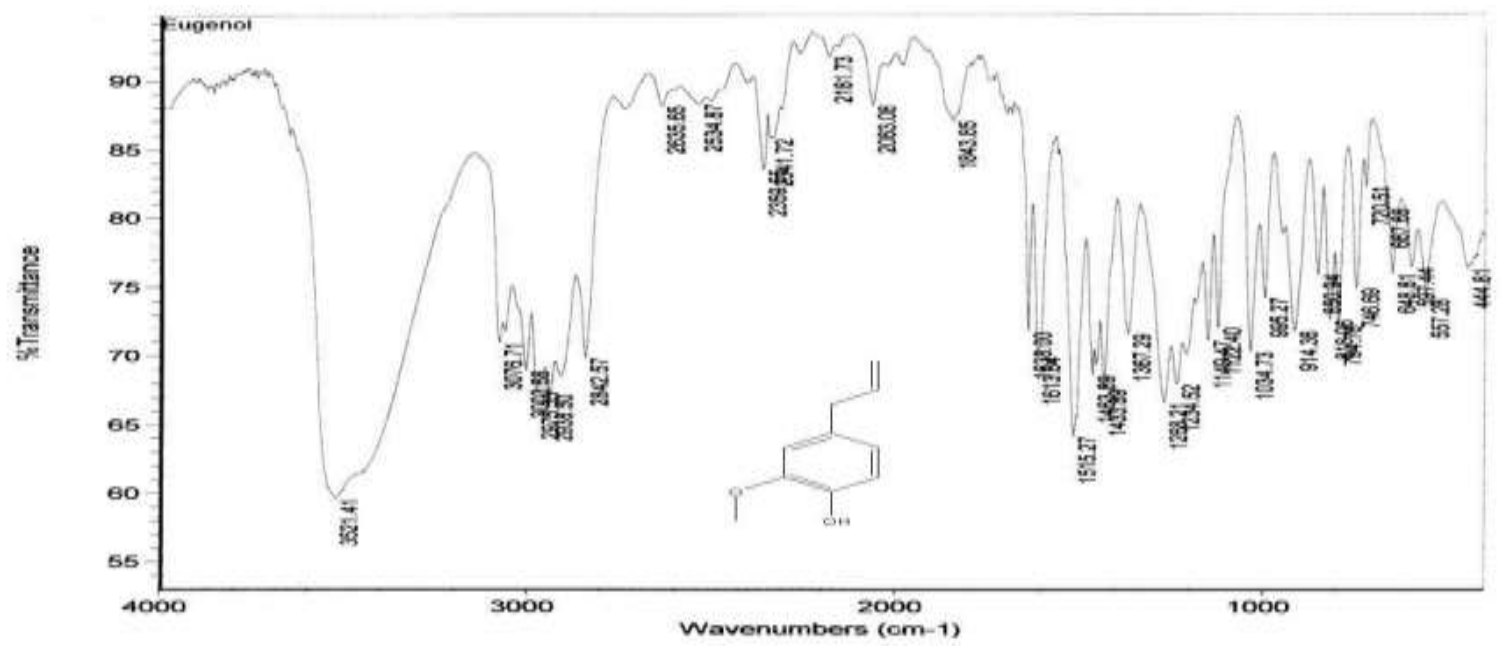

Gambar 2. Spektra FTIR Senyawa Eugenol

Tabel 1. Data Spektra FTIR Eugenol

\begin{tabular}{ccc}
\hline Serapan $\left(\mathbf{c m}^{-\mathbf{1}}\right)$ & $\begin{array}{c}\text { Gugus } \\
\text { Karakterisitik }\end{array}$ & Eugenol \\
\hline 3525 & Gugus Hidroksil & Ada \\
2972 dan 2841 & Gugus Karbon Jenuh & Ada \\
1636 & Jenuh & Ada \\
1608,25 dan 1513,37 & Gugus Aromatik & Ada \\
1431,1 & Gugus Metilen & Ada \\
996,25 dan 914,83 & Gugus H Vinil & Ada \\
818,63 & Aromatik & Ada \\
\hline
\end{tabular}

\section{Sintesis polieugenol dengan Katalis $\mathrm{H}_{2} \mathrm{SO}_{4}$}

Sintesis polieugenol dilakukan dengan menambahkan katalis $\mathrm{H}_{2} \mathrm{SO}_{4}$ pekat, polieugenol hasil sintensis dengan katalis $\mathrm{H}_{2} \mathrm{SO}_{4}$ pekat berbentuk padat dengan berat 3,166 gram, berwarna 
coklat tua dengan titik leleh berkisar $78-80{ }^{\circ} \mathrm{C}$. Poliegenol-polieugenol tersebut mempunyai sifat larut dalam eter, metanol, kloroform, benzena, dan etil asetat serta tidak larut dalam kerosen.

Proses polimerisasi eugenol menjadi polieugenol dapat ditunjukkan pada Gambar 3. Pada tahap inisiasi, katalis asam menyebabkan terjadinya reaksi adisi, sehingga gugus alil yang dimiliki oleh eugenol mengalami pemutusan ikatan rangkap. Pemutusan ikatan rangkap ini dapat terjadi karena proton $\left(\mathrm{H}^{+}\right)$dialihkan dari asam (katalis) ke monomer eugenol, terbentuk karbokation.

Pada tahap propagasi, terjadi pembentukan rantai dari monomer eugenol. Proses ini berkelanjutan sampai terbentuk rantai polimer yang panjang. Tahap terminasi merupakan tahap berakhirnya proses polimerisasi yaitu dengan menambahkan metanol untuk menghentikan pertumbuhan rantai. Dengan penambahan metanol maka diharapkan ujung akhir dari polimer tersebut adalah gugus metoksi.

Setelah proses polimerisasi selesai dilakukan, polieugenol yang terbentuk dilarutkan dalam dietileter dan dilakukan pencucian dengan akuades. Tujuan dari pencucian ini adalah untuk mendapatkan kembali katalis yang digunakan. Akuades yang tersisa pada polieugenol dihilangkan dengan menambahkan $\mathrm{Na}_{2} \mathrm{SO}_{4}$ anhidrat. Polieugenol yang telah kering (bebas dari akuades dan telah diuapkan pada suhu kamar) dilarutkan dengan akuades. Endapan yang terbentuk disaring dan ditimbang, kemudian dianalisis dengan FT-IR. Hasil polimerisasi eugenol menjadi polieugenol tampak pada spektra FT-IR seperti terlihat pada Gambar 3 dan 4 serta Tabel 2. Hasil analisis FTIR polieugenol nampak bahwa hilangnya spektra $-\mathrm{C}=\mathrm{C}$ pada panjang gelombang $1636 \mathrm{~cm}^{-1}$ dan $\mathrm{H}$ vinil pada bilangan gelombang $996,25 \mathrm{~cm}^{-1}$ dan $914,83 \mathrm{~cm}^{-1}$. Hal ini menunjukkan telah terjadi polimerisasi.

Tahap inisiasi

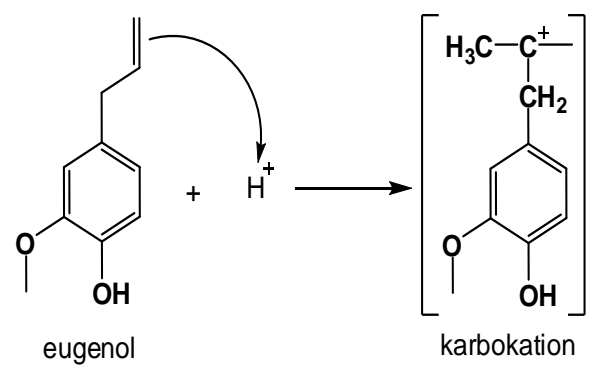

doi: http://dx.doi.org/10.23960/aec.v4.i2.2019.p14-29

Anal.Environ.Chem.Anal.Environ.Chem. 
Tahap propagasi

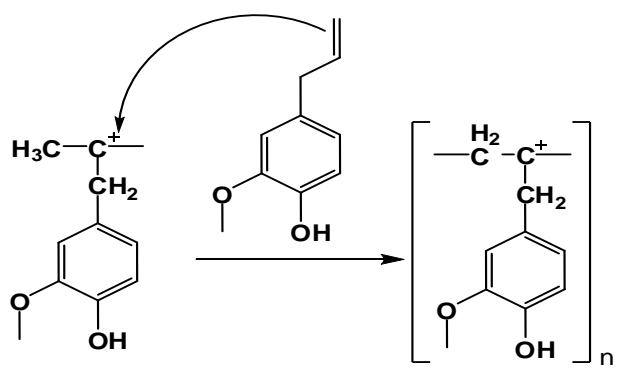

karbokation

rantai polimer

Tahap terminasi

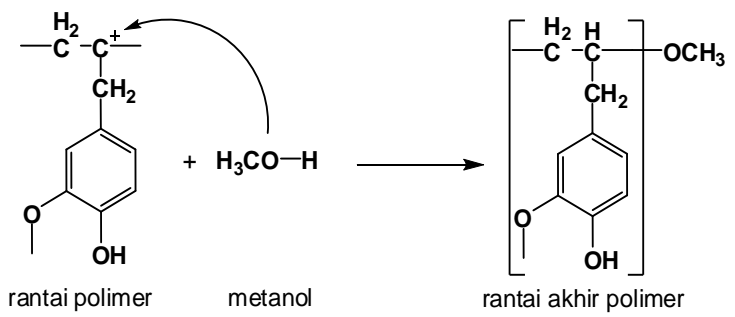

Jadi polimer yang terbentuk adalah sebagai berikut:<smiles></smiles>

Gambar 3. Mekanisme Pembentukan Polieugenol

Tabel 2. Data Spektra FTIR Polieugenol

\begin{tabular}{lll}
\hline Serapan $\left(\mathrm{cm}^{-1}\right)$ & \multicolumn{1}{c}{ Gugus Karakterisitik } & Polieugenol \\
\hline 3525 & Gugus Hidroksil & Ada \\
2972 dan 2841 & Gugus Karbon Jenuh & Ada \\
1636 & Gugus Karbon tak Jenuh & Tidak ada \\
1608,25 dan 1513,37 & Gugus Aromatik & Ada \\
1431,1 & Gugus Metilen & Ada \\
996,25 dan 914,83 & Gugus H Vinil & Tidak ada \\
818,63 & Aromatik Tersubstitusi & Ada \\
\hline
\end{tabular}

doi: http://dx.doi.org/10.23960/aec.v4.i2.2019.p14-29 


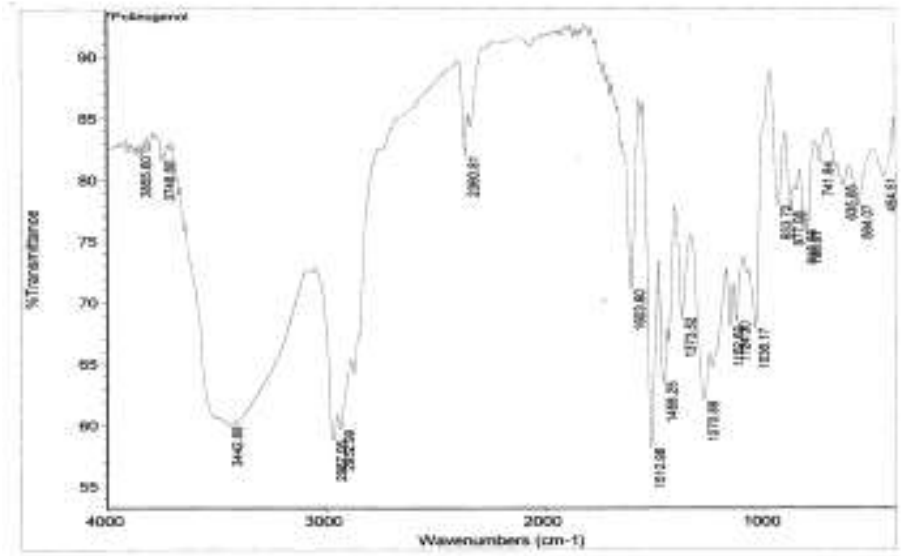

Gambar 4. Spektra FT-IR Polieugenol Hasil Sintensis

\section{Pengukuran Berat Molekul Polimer}

Berat molekul polieugenol diukur dengan metode viskometri menggunakan viscometer Ubbelhode. Polieugenol yang telah dilarutkan dalam methanol dan dibuat dalam berbagai variasi konsentrasi, diukur waktu alirnya, sehingga didapatkan $t_{1}, t_{2}$, dan $t_{3}$ untuk masing-masing polieugenol. Metanol sebagai pelarut juga diukur waktu alirnya, sehingga didapat $\mathrm{t}_{0}$. Dari ketiga data waktu alir tersebut dapat dibuat grafik hubungan konsentrasi dengan $\eta s p / C$, sehingga $\eta r e l$ dan $\eta s p$ dapat dihitung dan jumlah monomer yang menjadi polimer dapat diketahui. Untuk polieugenol hasil sintesis dengan katalis $\mathrm{H}_{2} \mathrm{SO}_{4}$ pekat, didapat data seperti pada Tabel 3 .

Dari Tabel 3 dan Gambar 5 dapat diketahui bahwa nilai $\eta s p$ semakin besar maka konsentrasi polieugenol semakin besar. Dengan persamaan Mark-Houwink-Sakurada $[\eta]=$ $K M v a$ (Rosenthal, 1990), didapat bahwa $[\eta]=$ intersep, maka $[\eta]=34,733$. Apabila harga $K=$ $11 \times 10^{-3}$ dan a $=0,725$ (Brandrup, 1975), maka :

$$
\begin{aligned}
M_{v} & =\exp \frac{\operatorname{In} \text { intersep }-\operatorname{Ink}}{a} \\
M_{v} & =\exp ^{\frac{\operatorname{In} 84,78 s-\operatorname{In} 0,011}{0,725}} \\
& =\exp ^{11,113} \\
& =66836,19
\end{aligned}
$$


Bila $\mathrm{Mr}$ eugenol = 164,2 maka dapat diketahui bahwa monomer eugenol yang menjadi polieugenol adalah sebanyak $\frac{66836,19}{164,2}=407,04=407$ monomer.

Table 3. Data Waktu Alir Metanol dan Polieugenol Hasil Sintesis dengan Katalis $\mathrm{H}_{2} \mathrm{SO}_{4}$ pekat

\begin{tabular}{|c|c|c|c|c|}
\hline $\mathrm{T}_{0}(\mathrm{~s})$ & $\mathrm{t}(\mathrm{s})$ & $\eta \mathrm{sp}$ & $(\mathrm{g} / \mathrm{mL})^{\mathrm{C}}$ & $(\mathrm{mL} / \mathrm{g})^{\eta \mathrm{sp} / \mathrm{C}}$ \\
\hline 95,812 & 120,868 & 0,261 & 0,01 & 26,100 \\
\hline 95,812 & 129,671 & 0,353 & 0,02 & 17,650 \\
\hline 95,812 & 130,007 & 0,357 & 0,04 & 8,925 \\
\hline
\end{tabular}

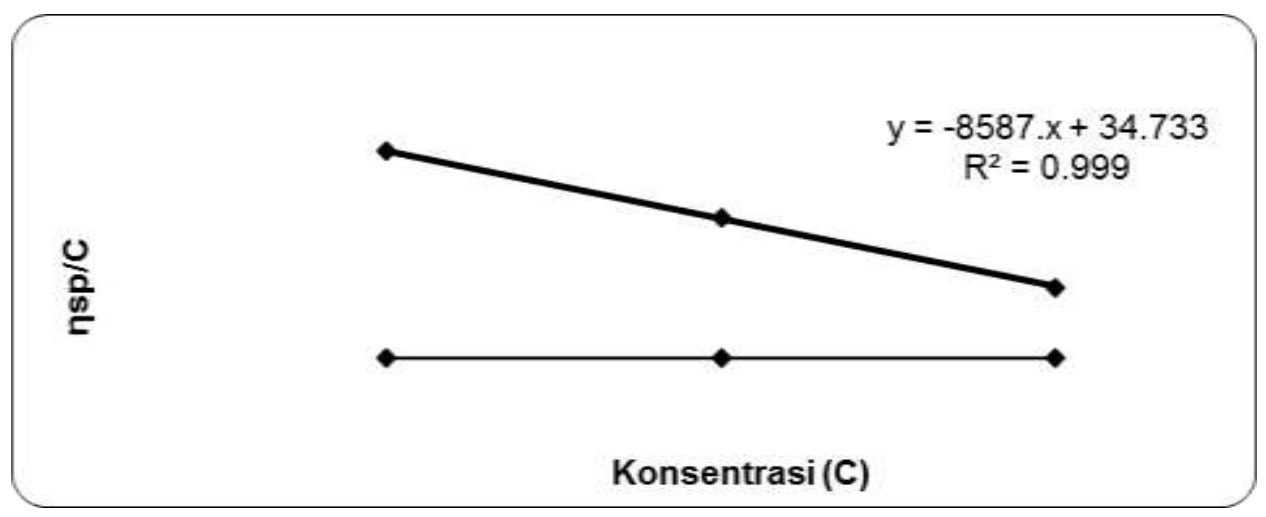

Gambar 5. Grafik Hubungan Konsentrasi dengan $\eta$ sp/Konsentrasi pada Polieugenol Hasil Sintensis dengan Katalis $\mathrm{H}_{2} \mathrm{SO}_{4}$

\section{Proses Reduksi Limbah Krom}

Proses reduksi $\mathrm{Cr}(\mathrm{VI})$ menjadi $\mathrm{Cr}(\mathrm{III})$ dilakukan dengan perlakuan sebanyak $50 \mathrm{~mL}$ limbah cair industri ditambah dengan $30 \mathrm{~mL} \mathrm{NaBH}_{4}$ dan $\mathrm{HCl}$ sampai $\mathrm{pH} 2$.

Senyawa $\mathrm{NaBH}_{4}$ merupakan senyawa pereduksi yang memiliki empat atom hidrida, Senyawa $\mathrm{NaBH}_{4}$ merupakan senyawa pereduksi yang memiliki empat atom hidrida, dengan adanya hidrida tersebut, maka $\mathrm{NaBH}_{4}$ akan mengalami oksidasi. Reaksi oksidasi senyawa $\mathrm{NaBH} 4$ tersebut diperkirakan sebagai berikut.

$$
3 \mathrm{BH}_{4}^{-}+6 \mathrm{OH}^{-} \longrightarrow 3 \mathrm{BO}_{2}^{-}+9 \mathrm{H}_{2}+6 \mathrm{e}^{-}
$$


Setelah dilakukan reduksi, warna limbah berubah dari warna kuning menjadi kehijauan. Hasil analisis UV-Vis diatas diperoleh bahwa $\mathrm{Cr}(\mathrm{VI})$ setelah direduksi berubah menjadi $\mathrm{Cr}(\mathrm{III})$. Hal ini dapat dilihat pada spektra UV-Vis limbah elektroplating $\mathrm{Cr}$ (VI) (Gambar 6) yang ditunjukkan dengan adanya 2 peak yang muncul pada panjang gelombang $275 \mathrm{~nm}$ dan panjang gelombang $345 \mathrm{~nm}$. Sedangkan pada spektra UV-Vis limbah (Gambar IV.8) setelah penambahan reduksi tidak ada peak yang muncul, hal ini disebabkan karena adanya perubahan $\mathrm{Cr}(\mathrm{VI})$ yang telah tereduksi menjadi Cr(III). Hasil reduksi dapat dilihat pada spectra UV-Vis (Gambar 6).

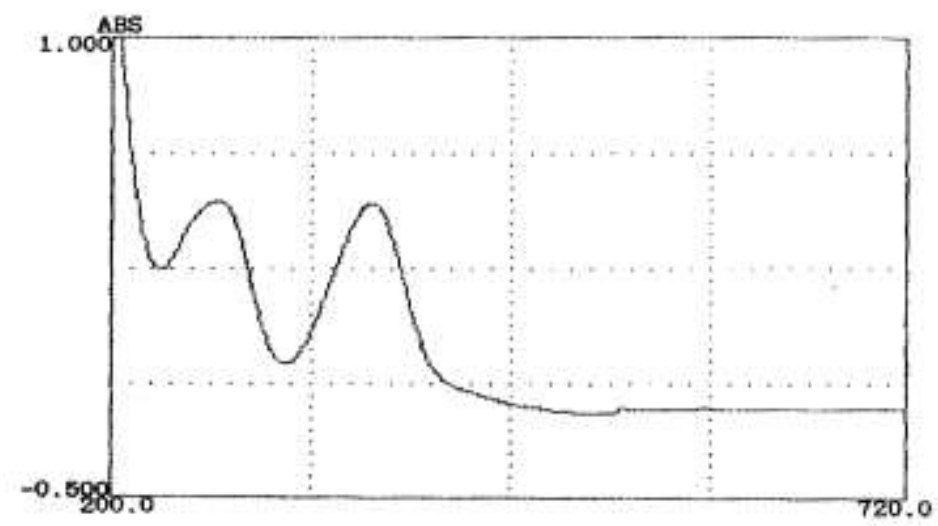

Gambar 6. Spektra UV-Vis Limbah Elektroplating Cr(VI)

\section{Pemisahan Ion Logam Krom dari Larutan Limbah Elektroplating dengan Teknik BLM (Bulk Liquid Membrane)}

Pemisahan logam berat dari larutan limbah elektroplating dapat dilakukan dengan teknik BLM (Bulk Liquid Membran), yaitu dengan mengontakkan fase umpan dengan fase membran dan fase membran dengan fase penerima pada sebuah tabung U. Fase umpan yang merupakan logam $\mathrm{Cr}^{3+}$ dikontakkan dengan fase membran yang merupakan larutan polieugenol (0,5 g polieugenol dalam 30ml kloroform). Kemudian fase membran dikontakkan dengan fase penerima yang merupakan larutan $\mathrm{HCl}$. Setelah dilakukan pengadukan selama 24 jam maka akan dapat diketahui transpor logam yang terjadi melalui perubahan $\mathrm{pH}$. merupakan logam $\mathrm{Cr}^{3+}$ dikontakkan dengan fase membran yang merupakan larutan polieugenol $(0,5 \mathrm{~g}$ polieugenol dalam 30ml kloroform). Kemudian fase membran dikontakkan dengan fase penerima yang 
merupakan larutan $\mathrm{HCl}$. Setelah dilakukan pengadukan selama 24 jam maka akan dapat diketahui transpor logam yang terjadi melalui perubahan $\mathrm{pH}$.

Tabel 4. Data Perubahan $\mathrm{pH}$ pada fase Umpan dan Fase Penerima

\begin{tabular}{llcc}
\hline \multicolumn{2}{c}{$\mathrm{pH}$ Fase Umpan } & \multicolumn{2}{c}{$\mathrm{pH}$ Fase Penerima } \\
\hline Mula-Mula & 24 jam & Mula-Mula & 24 jam \\
\hline 1,042 & 1,008 & 0,523 & 0,683 \\
3,084 & 1,207 & 0,523 & 0,425 \\
5,092 & 0,714 & 0,523 & 0,715 \\
7,071 & 0,734 & 0,523 & 0,742 \\
\hline
\end{tabular}

*Transpor dengan Polieugenol Hasil Sintesis dengan Katalis H2SO4 pekat

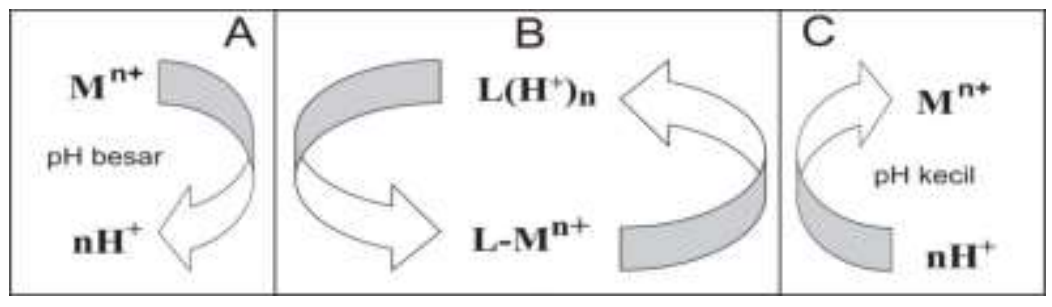

Gambar 7. Mekanisme Pertukaran ion pada Fase Umpan dan Fase Penerima

Keterangan gambar :

$\mathrm{A}=$ Fase Umpan

$\mathrm{B}=$ Fase Membran

$\mathrm{C}=$ Fase Penerima

$$
\begin{aligned}
M & =\text { Metal (logam) } \\
H & =\text { Hidrogen } \\
\mathrm{L} & =\text { Ligan }
\end{aligned}
$$

$\mathrm{n}=$ muatan logam

Dari data perubahan $\mathrm{pH}$ (Tabel 4) maka dapat diketahui bahwa transpor logam telah terjadi. Perubahan $\mathrm{pH}$ ini disebabkan karena adanya mekanisme pertukaran ion logam dari fase umpan dengan ion $\mathrm{H}^{+}$dari fase penerima. Fase umpan yang berisi ion logam $\mathrm{Cr}^{3+}$, akan berikatan dengan carrier dalam membran. Kemudian ion-ion logam tersebut akan dibawa oleh carrier menuju fase penerima. Logam akan dilepaskan di fase penerima dan dipertukarkan dengan ion $\mathrm{H}^{+}$yang ada di fase penerima. Setelah itu, carrier kembali lagi ke fase umpan, menukar dan 
mengambil kembali ion logam di fase umpan. Demikian proses ini terjadi secara terus menerus, sehingga $\mathrm{pH}$ fase umpan akan berubah menjadi lebih asam (Gambar 7).

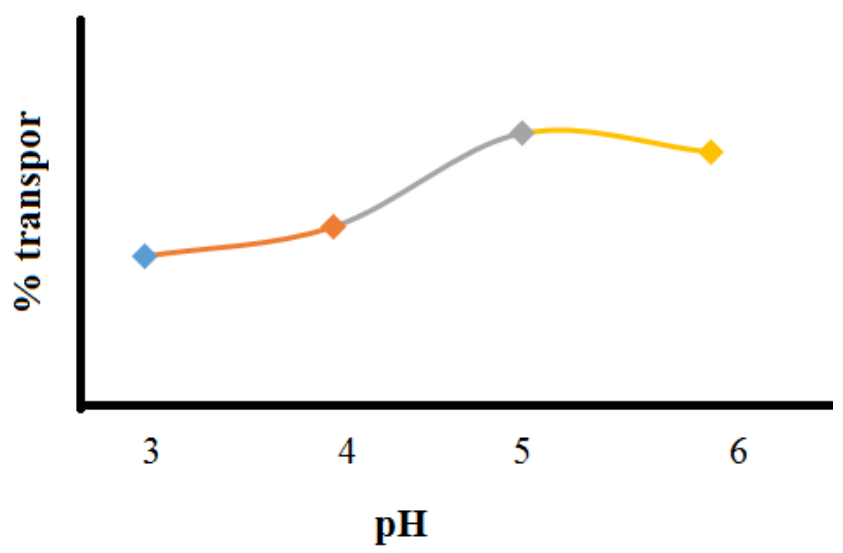

Gambar 8. Grafik Transport Logam Variasi pH

Dari Gambar 8 menunjukkan bahwa pada pH 5 menunjukkan kondisi yang optimal. Pada kondisi $\mathrm{pH}$ yang lebih rendah $(\mathrm{pH}$ 1) proses transport mengalami penurunan, juga pada $\mathrm{pH}$ yang semakin tinggi $(\mathrm{pH} 7)$ kembali mengalami penurunan. Hal ini karena semakin banyaknya jumlah $\mathrm{H}^{+}$di fasa umpan akan cenderung menaikkan interaksi antara senyawa pembawa dengan $\mathrm{H}^{+}$ sehingga terjadi efek persaingan jumlah ion $\mathrm{Cr}^{3+}$ yang bereaksi dengan senyawa pembawa menjadi berkurang, sedangkan pada $\mathrm{pH}$ penerima 7 juga memberikan hasil yang kurang optimal karena $\mathrm{Cr}$ (III) terdistribusi ke fasa membran kurang optimal.

Secara umum semakin tinggi beda $\mathrm{pH}$ antara fasa umpan dan fasa penerima, transport yang terjadi semakin baik. Hal ini dikarenakan transport membran cair yang menggunakan semua senyawa pembawa asam (penukar kation) dilakukan (driving force) oleh gradien konsentrasi ion $\mathrm{H}^{+}$antara fasa umpan dan penerima (Bartsch, 1996).

\section{KESIMPULAN}

Dari hasil penelitian yang telah dilakukan dapat diambil kesimpulan bahwa pemisahan ion logam $\mathrm{Cr}$ dari limbah elektroplating dengan teknik BLM (Bulk Liquid Membrane) dapat dilakukan dengan mengunakan polieugenol hasil sintesis. Sintesis polieugenol dapat dilakukan dengan menggunakan katalis $\mathrm{H}_{2} \mathrm{SO}_{4}$ pekat yang dimanfaatkan untuk proses pemisahan logam 
berat yaitu $\mathrm{Cr}^{3+}$. Hasil persen transport dengan senyawa pembawa polieugenol hasil sintesis dengan katalis $\mathrm{H} 2 \mathrm{SO} 4$ pekat dengan variasi $\mathrm{pH}$ pada fasa umpan adalah $\mathrm{pH} 1$ sebesar 20,88 \%, pH 3 sebesar 40,16 \%, pH 5 sebesar 101,42 \%, dan pH 7 sebesar 89,52 \%. Pada variasi pH fasa umpan pH 5 menunjukkan kondisi yang optimal dibandingkan dengan pH yang lainya.

\section{DAFTAR PUSTAKA}

Harimu, La, dkk., 2010, Pemisahan Ion Logam Berat Fe (III), Cr (III), Cu (II), Ni (II), Co (II), dan $\mathrm{Pb}$ (II) Menggunakan Pengemban Ion Poli (Asam Eugenil Oksiasetat) dengan Metode Transpor Membran Cair, Indonesian Journal Chemistry, Sulawesi Tenggara, p. 69-74.

Kaur, A., dan Vohra, D. K., 2010, Study of Bulk Liquid Membrane as A Separation Technique to Recover Acetic and Propionic Acids from Dilute Solutions, Indian Journal of Chemical Technology, India, p. 133-138.

Kiswandono, A.K. 2016. Review: Metode Membran Cair untuk Pemisahan Fenol. Anal.Environ.Chem. Vol. 1(1), 74-88.

Leon, Gerardo, dan Guzman, M. A., 2007, Facilitated Transport of Copper Through Bulk Liquid Membranes Containing different Carriers, Jurnal Alchemis, A Departement of Chemical and Engineering, Polytechnic University of Cartagena, Spanyol, p. 330-336.

Religa, P.,Gawronskri, R., dan Gierycz, P., 2009, Kinetics of Chromium (III) Transport Through a Liquid Membrane Containing DNNSA as A Carrier, Internasional Journal of Molecular Sciences, Polandia, p. 964-975.

Silva, B., Figueiredo, H., Neves, I. C., dan Tavares, T., 2009, The Role of pH on Cr (VI) Reduction and Removal by Arthrobacter Viscosus, International Journal of Chemical and Biological Engineering, p. 100-103.

Sudarma, I made, Ulfa, M., dan Sarkono, 2009, Chemical Transformation of Eugenol Isolated from Clove Oil to 4-Allyl-2-Methoxy-6-Sulfonicphenol and 4-Allyl-2-Methoxy-6Aminophenol, Indonesian Journal Chemist, p. 267-270. 